\title{
Teen Athletes: Facebook, Self Esteem and Self Perception
}

\author{
Anna Kariou, Panagiotis Antoniou, Evangelos Bebetsos, and Kasampalis Athanasios
}

\begin{abstract}
In this research we examined the social network use, and more precisely, the use of Facebook, and the impact on psychological factors such as self esteem and overall self perception. The participants were 87 teen athletes from sports such as basketball, volleyball and football. Results indicated that self esteem played a major role in the behaviour of children. Six Facebook factors were analysed: behavioral intention, satisfaction, using applications, time waste, social connection and social surfing. Finally the research pointed out where is the connection between social surfing, using applications, self esteem, self perception of athletic ability and self perception of physical appearance.
\end{abstract}

Index Terms-Behavior, self-esteem, social media, teenage athletes.

\section{INTRODUCTION}

A very large portion of the modern world use internet and social networks as part of their daily routine. Nowdays internet and social networks are powerful means because through them one can find information in every topic, entertainment, work from home, talk and exchange new ideas.

The development of technology in the area of exchange information and interaction between people led to the emerging of social networks. The social networks' sites are virtual communities that allow people to communicate and interact in a direct, quick, inexpensive and fun way [1]. The rate of growth is rapid [2]. Within a few years, they have been appeared too many meeting places such as: Facebook, Twitter, MySpace, Hi5, Orkut, Badoo, Digg, Ning, Tuenti.

However, the phenomenon is relatively new and the results of researchers are contradictory. Some of these studies show that the overuse leads to loneliness and isolation [3]. But on the other hand, other studies argue that the use of the Internet and particularly of social networks, leads to a positive development of social and psychological characteristics of users [4].

In this paper, from now on, the term social network will stand for Facebook. This social network is the most popular among people of any age. Based on data from the official page of Facebook of March 2013, 751 million users visited the facebook network from mobile phones, 655 million users from other devices per day, 1.11 billion users per month and 79 percent of all users come from countries outside the United States.

Manuscript received August 14, 2014; revised October 24, 2014

The authors are with the Democritus University of Thrace, Greece (e-mail: akariou@phyed.duth.gr,panton@phyed.duth.gr,empempet@phyed.duth.gr, akasampa@phyed.duth.gr).

\section{THEORETICAL BACKGROUND}

The issues that concern us in this paper are the use of facebook and dimensions of self-esteem and self-perception in a group of teenage athletes. However, it is extremely difficult to find scientific references dealing with the combination of the two factors.

A similar survey took place in Greece in 2012, the results agreed with same studies abroad as for example the study of Coley (2006) [5]. In brief they found that the use of Facebook affects mainly three factors, social contact (social connection), leisure (wasting time), and finally the use of applications (using apps). In conjunction with the study of Coley (2006), it seems that the factor that most affects the use of the world's most famous social network is the factor 'free time'. According to Coley (2006) [6], students are using Facebook, primarily for recreational purposes, for organizing parties and finding a partner on a daily basis. Based on this reasoning, the above researchers, Giannakos et al., 2012, published three articles. Results showed that the most important factors are social contact and leisure. The research showed that social contact is the main reason for attracting new users. From a gender perspective, women use more applications on Facebook and less browsing activity (social surfing).

Another research, by Christh et al., 2010, showed that the main reason students use Facebook is to present themselves socially. Moreover people who realize that they have many things in common tend to use Facebook more often. But when people end up being members in many facebook groups they lose their sense of belonging to a particular group. In conclusion the study found two factors that influence the use of Facebook, the entertainment factor (entertainment) and the social interaction (social related factors).

Lampe et al. [7] and Vasalou et al. [8] found similar results. Differences are only in terminology. The axes of applications (using apps) are defined as "games and applications" (games and applications) and the factor "browsing the Internet" and Facebook (social surfing) is defined as "social browsing".

Another research that conducted in 2010 by Linda et al. [9], supply us with very interesting data on the use of internet in relation to self-esteem and the students in relation to the image of their body. In comparison to other studies, in Linda's study, was shown how there is a link between the use of technology and body weight. There was a positive correlation between the use of the internet and self-esteem. Finally videogames, which is part of Facebook, had a negative correlation in relation to self-esteem, maybe because videogames are a solitary activity.

In another survey based on the experience of the participants, Ohbyung et al. [10], 2010, considered in general the factors that may influence the use of social networks. 
Resulted in three factors, social identity (social identity), altruism (altruism) and telepresence (telepresence). The results showed that telepresence, was among the strongest factors because is directly related to the choice of the network, for example Second Life network. Users want to have intense emotional interaction between them. On the other hand, altruism hides a very basic principle that all social networks have. The user acknowledges that the current social network is a very good tool through which can share feelings and messages. Referring now to the social identity researchers found that people who have higher level of social identity are more likely to express feelings of pride and send more positive messages.

One of the few studies that addresses the issue of self-esteem in relation to the use of social networks is of Wang et al., held in 2012 [11]. Based on the view that individual personality traits are affected by the use of social networks, they examined the five most typical factors that make up human personality. The researchers define self-esteem as the overall self-assessment of the value of the person (Weiten, 2004). Previous research in the field, such as Joinson, 2004 and Phillip et al., 2006, was showing the relationship between self-esteem and use of social networks as a communication tool, because they have the ability to reduce levels of social anxiety, that people with low self-esteem experience in face-to-face contacts. The results showed that, contrary to the initial research hypothesis, individuals had positive interaction between self-esteem and comments that post on the network. This result is probably due to the fact that these people had great confidence in themselves and they wanted to tell their opinion and view their uploading comments.

In a study on Greek population [12], with a sample of 332 sixth grade children, was found a positive association between physical activity and self-esteem, positive correlation between physical activity and self-perception in terms of athletic ability, as well as positive correlation between self-esteem and self-concept in terms of athletic ability. The results were very satisfactory as it agrees with the literature until now.

\section{METHODOLOGY}

\section{A. Participants}

Participants of the research were teenage athletes from Thessaloniki, Greece. The participation in the survey was voluntary. The total sample was 87 athletes, 62 boys and 25 girls. Regarding the sports, 18 boys were basketball player, 44 boys were football player and 25 girls were volleyball players. Finally 70 athletes were users of Facebook and 17 were not. From the users of Facebook we found out that the average time they spend to Facebook per week is 8,28 hours and the average number of friends they had were 987,23. The results of the demographics are presented in Table I.

\section{B. Data Collection}

The collection of data for the self esteem and self perception factors were made through the utilization of the self perception profile questioner for children (Harter). The self perception profile questioner for children (Harter) [13] was already translated for Greek children from Mpotsari Makri Eui in 2001. In the Greek version all the scales were valid and reliable to the Greek population and were also made new norms for the Greek population too. The questioner had 10 scales and approximately 50 to 60 questions depending on the age of the participant.

The collection of data for the use of Facebook were made through the utilization of a questioner, primary used in the research of Giannakis et al. (2010), the title of the questioner was: Investigating Facebook Usage Factors and Perceptions. The questioner had 7 scales and 32 questions.

TABLE I: DEMOGRAPHICS

\begin{tabular}{|l|l|l|l|}
\hline Demographics & Numder & \% Percent \\
\hline \multirow{3}{*}{ Gender } & Female & 25 & 28,7 \\
\cline { 2 - 4 } & Male & 62 & 71,3 \\
\hline \multirow{3}{*}{ Sport of } & Yolleyball & 25 & 28,7 \\
\cline { 2 - 4 } & Basketball & 18 & 20,7 \\
\cline { 2 - 4 } & Football & 44 & 50,6 \\
\hline \multirow{2}{*}{$\begin{array}{l}\text { Facer } \\
\text { Time spend on each week } \\
\text { (hours) }\end{array}$} & Mean $=8,28$ & 80,5 \\
\hline $\begin{array}{l}\text { Number of friends on } \\
\text { Facebook }\end{array}$ & Mean=987,23 \\
\hline
\end{tabular}

\section{Data Analysis}

The software used for data analysis was SpSS 16.0 and E-Views 8. The statistical analysis used descriptive statistical analysis on quantitative and qualitative variables. All quantitative variables were checks for independence. Analysis of variance was applied for testing the difference between groups in independent samples. Then factor analysis was applied to select only one variable from each group, the variable with the biggest loading. Next Pearson and Spearman correlation coefficient was tested.

\section{RESUlTS}

In this section are presented Hypothesis testing and correlation of variables for the psychometric properties, along with the measures of the use of Facebook and demographics of the sample.

\section{A. Factors Analysis of Psychometric Properties and Demographics}

The hypothesis testing and the ANOVA tests showed no significant difference between athletes who are users of Facebook among athletes who do not use Facebook and self-esteem $(p$-value $=0.600>0.05)$. The same results continues for the factor of self-perception in sports ability ( $p$-value $=0.492>0.05)$, self-concept in physical appearance $(p$-value $=0.806>0.05)$, self-perception and best friends $(p$-value $=0.564>0.05)$.

In order to observe statistically significant differences between gender and psychometric properties we applied again analysis of variance ANOVA and the results were as follows. There is no significant difference between gender and self esteem $(p$-value $=0.615>0.05), \quad$ gender and 
self-perception in sports ability ( $p$-value $=0.917>0.05)$ and self-concept in physical appearance ( $p$-value $=0.658>0.05)$. But the results showed that there are significant differences between gender and self-perception of friendship and best friend's relationships. ( $p$-value $=0.041<0.05)$.

Now regarding the question if self esteem of athletes can influence the self perception in sports ability, the results from the analysis of variance ANOVA, showed that the self esteem is influenced by the self perception of athletic capability ( $p$-value $=0,0002)$. In the same pace the results showed that there is significant differences between self esteem and self-perception in physical appearance $(p$-value $=0,003)$ and finally self esteem and self-perception in friendship $(p$-value $=0,00)$.

In the process of analysing the data we checked any linear correlation between the self esteem and the hours someone spend online on the Facebook page and the self esteem and the number of Facebook friends. No linear correlations have been found in any of these factors that were tested.

\section{B. Factors Analysis of the Use of Facebook}

In this paper, factor analysis was selected in order to select a variable from each group that will give the largest load. If for example we want to consider the «social connection» as one variable the selected variable will be «reconnect with people I have lost contact with» having the largest load (loading). Similar procedure was followed for the study of other groups of variables. The results for each group are as follows in Table II-Table VII. Please note that the Cronbach Alpha value greater than 0.7 indicates high reliability in the group.

\section{TABLE II: FACTOR SOCIAL CONNECTION}

\begin{tabular}{|l|l|l|l|}
\hline $\begin{array}{l}\text { Factor: Social } \\
\text { Connection } \\
\text { Cronbach's Alpha=,745 }\end{array}$ & Mean & S. D. & Loadings \\
\hline $\begin{array}{l}\text { communicate with people } \\
\text { who are away } \\
\text { communicate with people } \\
\text { who i have long time to } \\
\text { see } \\
\text { reconnect with people who } \\
\text { i have lost contact } \\
\text { finding out what my old } \\
\text { friends do }\end{array}$ & 3,6232 & 1,66364 &, 672 \\
\hline
\end{tabular}

TABLE III: FACTOR SOCIAL SURFING

\begin{tabular}{|l|l|l|l|}
\hline $\begin{array}{l}\text { Factor: Social Surfing } \\
\text { Cronbach's Alpha=,788 }\end{array}$ & Mean & $\begin{array}{l}\text { Std. } \\
\text { Deviation }\end{array}$ & Loadings \\
\hline $\begin{array}{l}\text { Looking at the profiles of people } \\
\text { you don't know } \\
\text { looking at the profiles of friends } \\
\text { of my friends } \\
\begin{array}{l}\text { Viewing photos of people you } \\
\text { don't know }\end{array}\end{array}$ & 1,9857 & 1,52746 &, $\mathbf{9 0 3}$ \\
\hline
\end{tabular}

TABLE IV: FACTOR: WASTING TIME

\begin{tabular}{|l|l|l|l|}
\hline $\begin{array}{l}\text { Factor: Wasting Time } \\
\text { Cronbach's Alpha=,797 }\end{array}$ & Mean & $\begin{array}{l}\text { Std. } \\
\text { Deviation }\end{array}$ & Loadings \\
\hline To spent my time & 3,9565 & 1,89764 &, 702 \\
To kill my time & 2,9710 & 1,83087 & $\mathbf{, 8 0 3}$ \\
Just for fun & 3,0290 & 1,90950 &, 800 \\
To fill up free time & 3,1014 & 1,88761 &, 742 \\
From habbit & 3,0870 & 1,73832 &, 664 \\
\hline
\end{tabular}

TABLE V: FACTOR USING APPLICATIONS

\begin{tabular}{|l|l|l|l|}
\hline $\begin{array}{l}\text { Factor Using } \\
\text { Applications } \\
\text { Cronbach's Alpha=,839 }\end{array}$ & Mean & $\begin{array}{l}\text { Std. } \\
\text { Deviation }\end{array}$ & Loadings \\
\hline $\begin{array}{l}\text { Using various fb } \\
\text { applications } \\
\text { Playing games } \\
\begin{array}{l}\text { Trying applications } \\
\text { because you see your } \\
\text { friends have udes them }\end{array}\end{array} \quad 1,9710$ & 1,9526 &, 916 \\
\hline
\end{tabular}

TABLE VI: FACTOR SATISFACTION

\begin{tabular}{|l|l|l|l|}
\hline $\begin{array}{l}\text { Factor Satisfaction } \\
\text { Cronbach's Alpha=,801 }\end{array}$ & Mean & Std. Deviation & Loadings \\
\hline $\begin{array}{l}\text { I am satisfied with the use of } \\
\text { facebook }\end{array}$ & 4,2899 & 1,56338 &, 890 \\
$\begin{array}{l}\text { I am pleased with the use of } \\
\text { facebook } \\
\text { My decision to use facebook } \\
\text { was a wise one }\end{array}$ & 4,3478 & 1,45346 &, 934 \\
\hline
\end{tabular}

TABLE VII: FACTOR BEHAVIORAL INTENTION

\begin{tabular}{|l|l|l|l|}
\hline \begin{tabular}{l} 
Factor $\begin{array}{c}\text { Behavioral } \\
\text { Intention } \\
\text { Alpha }=, 892\end{array}$ \\
\hline $\begin{array}{l}\text { I intend to use facebook in } \\
\text { the future }\end{array}$
\end{tabular} & Mean & Std. Deviation & Loadings \\
$\begin{array}{l}\text { I will continue using fb in } \\
\text { the future }\end{array}$ & 4,8261 & 1,69473 &, 939 \\
$\begin{array}{l}\text { I will regularly use fb in the } \\
\text { future }\end{array}$ & 3,9130 & 1,69549 &, 941 \\
\hline
\end{tabular}

TABLE VIII: PEARSON AND SPEARMAN CORRELATIONS

\begin{tabular}{|l|l|l|l|l|l|}
\hline \multirow{2}{*}{} & & $\begin{array}{l}\text { Athletic } \\
\text { Ability }\end{array}$ & $\begin{array}{l}\text { Physical } \\
\text { appearan } \\
\text { ce }\end{array}$ & $\begin{array}{l}\text { Best } \\
\text { Friends }\end{array}$ & $\begin{array}{l}\text { Self } \\
\text { esteem }\end{array}$ \\
\hline \multirow{2}{*}{$\begin{array}{l}\text { Social } \\
\text { Connection }\end{array}$} & Pearson & 0.505 & 0.657 & 2.252 & 0.370 \\
\cline { 2 - 6 } & Spearman & 0.725 & 0.823 & 0.113 & 0.489 \\
\hline $\begin{array}{l}\text { Social } \\
\text { Surfing }\end{array}$ & Pearson & $\mathbf{0 . 0 3 1}$ & $\mathbf{0 . 0 3 5}$ & 0.708 & 0.968 \\
\cline { 2 - 6 } & Spearman & $\mathbf{0 . 0 1 4}$ & 0.062 & 0.727 & 0.840 \\
\hline \multirow{2}{*}{$\begin{array}{l}\text { Wasting } \\
\text { Time }\end{array}$} & Pearson & 0.713 & 0.743 & 0.338 & 0.755 \\
\cline { 2 - 6 } & Spearman & 0.506 & 0.864 & 0.320 & 0.804 \\
\hline $\begin{array}{l}\text { Using } \\
\text { Applicatio } \\
\text { n }\end{array}$ & Pearson & 0.401 & 0.010 & 0.641 & $\mathbf{0 . 0 0 7}$ \\
\cline { 2 - 6 } & Spearman & 0.369 & $\mathbf{0 . 0 2 1}$ & 0.834 & $\mathbf{0 , 1 2}$ \\
\hline \multirow{2}{*}{$\begin{array}{l}\text { Satisfactio } \\
\mathrm{n}\end{array}$} & Pearson & 0.787 & 0.449 & 0.564 & 0.308 \\
\cline { 2 - 6 } & Spearman & 0.455 & 0.449 & 0.459 & 0.282 \\
\hline \multirow{2}{*}{$\begin{array}{l}\text { Behavioral } \\
\text { Intention }\end{array}$} & Pearson & 0.498 & 0.449 & 0.308 & 0.308 \\
\cline { 2 - 7 } & Spearman & 0.369 & 0.449 & 0.282 & 0.282 \\
\hline
\end{tabular}

Pearson correlation coefficient and Spearman correlation coefficient determine if there is a correlation between self-perception as to athletic ability, self-perception as to their close friends, the self-perception in physical appearance and self-esteem. The results are shown in Table VIII.

From Table VIII we observe that there are correlations between the variables:

1) Social surfing and self-perception of athletic ability

2) Social surfing and self-perception of physical appearance

3) Using applications and self-perception of physical appearance 
4) Using applications and self-esteem

\section{DISCUSSION AND CONCLUSION}

The aim of this study was to explore whether or not a social network can affect the self esteem and self perception of teenaage athletes by using the most widely known social network platform, Facebook. This paper presents the results of the four psychometric factors (self esteem, self perception of athletic ability, self- perception of physical appearance and self- perception of friendship) and the results of the six factors regarding Facebook use.

On the first part of the study, the results showed that only a very small number of children do not have a Facebook account, not yet at least. The girls tend to give much importance to the factor of gender relations, friendship and best friends relationships in comparison to the boys. Also, the self-esteem factor, as expected, appears to affect all the other psychometric factors (self perception of athletic ability, physical appearance and friendship.)

On the second part of the study, the results showed exactly what was expected according to the researchers until today [14] and previous ones [15]. In the social connection factor results pointed out the aspect that Facebook enable someone to trace people from their own past. In the social surfing factor results pointed out the aspect that Facebook enable users to find information about totally strangers. In the "waste of time" factor results pointed out the importance of Facebook in everyday life as a tool for spending time. Finally in the "using of apps" factor results pointed out that Facebook attract users only for this feature and in some cases they use the applications because someone else is already using them.

The most interesting results came from the last part of this study. Social surfing and using applications factors have had the most important impact in this study, along with the athletic ability, physical appearance and self esteem variables.

We might argue that the action of social surfing can be influenced by the self-perception regarding athletic ability and physical appearance in the activity of looking at strangers' profiles. And we might also argue that the action of application use can potentially be influenced by the self-perception of physical appearance and self-esteem in the activities of using various Facebook applications and trying applications because someone else used/uses them.

Of course there is no doubt that further research must be made in order to obtain more measures, with different and larger samples and be led to more reliable conclusions.

\section{REFERENCES}

[1] M. K. Christy, P.-Y. Chiu, and K. O. Matthew, "Online social networks: why students use facebook?" Computers in Human Behavior, vol. 27, pp. 1337-1343, 2011.

[2] Hitwise, Social Networking Visits Increase 11.5 Percent from January to February, December 23, 2007

[3] Y. A. Hamburger and E. B. Artzi, "Loneliness and internet use," Computers in Human Behavior, vol. 19, pp. 71-80, 2003.

[4] A. J. Linda, A. V. Eye, E. F. Hiram, A. W. Edward, and Z. Yong, "Internet use videogame and cell phone use as predictors of children's body mass index (IBM), body weight, academic performance and social and overall self-esteem," Computers in Human Behavior, vol. 27, pp. 599-604, 2011.

[5] M. N. Giannakos, A. Pateli, and K. Chorianopoulos, "Investigating Facebook's acceptance and satisfaction: a study in the greek university community," Social and Humanistic Computing, vol. 2, pp. 104-117, 2013.

[6] T Coley, Students and Cyber Communities, University of South Carolina, 2006.

[7] C. Lampe, N. Ellison, and C. Steinfield, "A Facebook in the crowd: social searching vs. social browsing," in Proc. the ACM Special Interest Group on Computer-Supported Cooperatative Work, ACM Press, pp. 167-170.

[8] A. Vasalou, A. N. Joinson, and D. Courvoisier, "Cultural differences, experiences with social network and the nature of true commitment in Facebook," International Journal of Human-Computer Studies, vol. 68, pp. 719-728, 2010.

[9] K. Ohbyung and W. Yixing, "An empirical study of the factors affecting social network service use," Computers in Human Behaviour, vol. 26, pp. 254-263, 2010.

[10] J.-L. Wangl, "The relationship among the Big Five Personality factors, self esteem, narcissism and sensation seeking to Chinese University students' uses of social uses of social network sites," Computers in Human Behavior, Article in press, 2012.

[11] E. Pieri, The Impact of Physical Activity on the Self-Esteem of a Child, Harokopio University Press, 2005

[12] S. Harter, Manual for the Self Perception Profile for Children, Denver, CO: University of Denver Press, 1985.

[13] M. E. Mpotsari, How do We Perceive Myself III \& IV, Ellinika Grammata Press, 2001

[14] M. N. Giannakos, K. Chorianopoulos, and K. Giotopoulos, Mind Trek Proceedings, ACM New York, pp. 153-157, 2010.

[15] M. N. Giannakos, K. Chorianopoulos, K. Giotopoulos, and P. Vlamos, "Using Facebook out of habit," Behaviour and Information Technology, pp. 1-9, 2012.

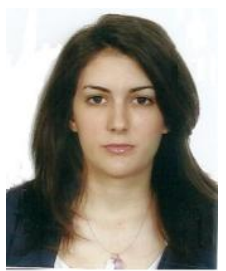

Anna Kariou was born in 1987 at Thessaloniki, Greece. She has a bachelor and master degree in psychology and school psychology. she is currently a postgraduate student in sport science, Department of Physical Education and Sport Science, Democritus University of Thrace, Greece. 